\title{
AKTIVITAS SITOTOKSIK EKSTRAK KARANG LUNAK Xenia sp. DARI TELUK MANADO, PROVINSI SULAWESI UTARA
}

\author{
(Cytoxic Activity of Soft Coral Extract Xenia sp. Manado Bay, North Sulawesi \\ Province)
}

\author{
Juniarti S. Datula'bi ${ }^{1 *}$, Robert. A. Bara ${ }^{1}$, Fitje Losung ${ }^{2}$, Remy E.P. Mangindaan ${ }^{2}$ \\ Ping Astony Angmalisang ${ }^{2}$, Rose O.S.E. Mantiri ${ }^{3}$ \\ 1. Mahasiswa Program Studi IImu Kelautan, FPIK, UNSRAT Manado \\ 2. Staf Pengajar Program Studi IImu Kelautan, FPIK, UNSRAT Manado \\ 3. Staf Pengajar Program Studi Manajemen Sumberdaya Perairan, FPIK UNSRAT \\ Manado
}

Penulis korespondensi: Juniarti S. Datula'bi; juniartistevi@yahoo.co.id

\begin{abstract}
Bioactive compounds from the sea which are generally in the form of secondary metabolites have the potential to be developed as medicinal ingredients. Marine life can be used as an object of research and development, considering the many benefits that can be taken from the secondary metabolite compounds contained in it, especially compounds that have bioactivity. Soft corals are marine biota that have bioactivity, extracts from sost coral contain bioactive compounds that have cytotoxic, anti-tumor, anti-viral, anti-inflammatory, anti-fungal, anti-leukemic, and enzyme activity inhibitory properties. Some of the research results show that marine soft corals have a variety of structures and biological activities including antioxidant substances. Soft corals were extracted by maceration method and then evaporated. The cytotoxic activity of soft coral extract was tested using the BLSA method and then analyzed the data to find the concentration of mortality (LC50). The purpose of this study was to test the cytotoxic activity of soft coral Xenia sp. The results of this study were testing the cytotoxic activity of the sample Xenia sp., amounting to $20.89 \mathrm{ppm}$, and having strong toxic properties.
\end{abstract}

Keywords: BLSA, Soft coral Xenia sp., LC 50 , Cytotoxic

\begin{abstract}
ABSTRAK
Senyawa bioaktif dari laut yang secara umum berupa senyawa metabolit sekunder sangat potensial untuk dikembangkan sebagai bahan obat. Biota laut dapat dijadikan sebagai objek penelitian dan pengembangan, mengingat banyaknya manfaat yang dapat diambil dari senyawa-senyawa metabolit sekunder yang terkandung di dalamnya terutama senyawa yang memiliki bioaktivitas. Karang lunak adalah biota laut yang memiliki bioaktivitas, ekstrak dari karang lunak mengandung senyawa bioaktif yang mempunyai sifat sitotoksik, anti tumor, anti virus, anti inflamasi, anti fungi, anti leukemia, dan penghambat aktivitas enzim. Beberapa dari hasil penelitian menunjukkan bahwa biota laut karang lunak memiliki keragaman struktur dan aktivitas biologi termasuk substansi antioksidan. Karang lunak diekstraksi dengan metode maserasi kemudian dievaporasi. Aktivitas sitotoksik ekstrak karang lunak diuji menggunakan metode BLSA kemudian dilakukan analisis data untuk mencari konsentrasi kematian $\left(\mathrm{LC}_{50}\right)$. Tujuan dari penelitian ini yaitu menguji dan mengetahui aktivitas sitotoksik karang lunak Xenia sp. Hasil dari penelitian ini yaitu pengujian aktivitas sitotoksik pada sampel Xenia sp., sebesar 20,89 ppm, dan memiliki sifat toksik yang kuat.
\end{abstract}

Kata kunci: BLSA, karang lunak Xenia sp., LC 50 , Sitotoksik 


\section{PENDAHULUAN}

Indonesia merupakan negara kepulauan terbesar yang terletak di wilayah khatulistiwa, sehingga menjadikan negara kita memiliki kekayaan biodiversitas yang tinggi. Kekayaan biodiversitas tersebut ditunjukkan dengan adanya biota laut yang memiliki senyawa bioaktivitas yang tinggi dan dapat dikembangkan dalam bidang farmakologi. Sehingga lingkungan laut merupakan sumber senyawa bioaktif yang sangat melimpah. Senyawa bioaktif merupakan senyawa metabolit sekunder sangat potensial untuk dikembangkan sebagai bahan obat. Senyawa bioaktif dari lingkungan laut juga dapat dijadikan sebagai senyawa pemandu (lead compound) dalam sintesis obat-obatan baru (Nursid $d k k$., 2006). Pencarian senyawa aktif metabolit sekunder dari biota laut yang potensial dari tahun 1990 2009 mengalami peningkatan jumlah senyawa alami yang ditemukan (Leal $d k k ., 2012)$.

Karang lunak merupakan
salah satu kelompok hewan invertebrata dari ekosistem terumbu karang, termasuk dalam keluarga Cnidaria, kelas Alcyonaria dan famili Alconiidae, terdistribusi dari Afrika Timur sampai Barat Samudera Pasifik (Radjasa dkk., 2007).

Karang lunak kaya akan senyawa bioaktif seperti terpenoid, steroid glikosida, flavonoid, fenol, saponin, dan peptida. Metabolit sekunder yang dihasilkan oleh karang lunak memiliki aktivitas biologi seperti anti fungi, anti neoplastik, antimikroba, inhibitor HIV dan anti inflamasi. Hasil penelitian menyatakan bahwa sekitar 50\% ekstrak karang lunak menunjukkan sifat racun pada ikan (Radhika, 2006).

Xenia sp., termasuk genus karang lunak dalam keluarga Xeniidae. Mereka menyerupai jamur, dengan "tangan" keluar dari atas yang berakhir dengan "tangan" berjari banyak. Hal ini termasuk unik di antara karang karena kemampuannya untuk menggunakan tangannya untuk mendorong air menjauh dari koloni dalam gerakan yang konstan dan menggenggam. Spesies Xenia kadang-kadang disebut sebagai nadi karang. Xeniidae terdiri dari 20 genera dan 162 spesies (Cordeiro dkk., 2019), dan dapat ditemukan terutama di Laut Merah dan Samudra Hindia dan Pasifik.

Tujuan dari Penelitian ini adalah menguji dan mengetahui aktivitas sitotoksik dari karang lunak Xenia sp., dengan menggunakan metode Brine Shrimp Lethality Assay (BSLA) ini merupakan cara yang digunakan untuk mengetahui kemampuan toksik terhadap sel (sitotoksik) dari suatu bahan atau zat yang diuji (Kanwar, 2007). Metode ini menggunakan larva udang (Artemia salina Leach) pada pengujiannya dengan waktu pengerjaannya yang cepat, mudah, tidak memerlukan peralatan dan keahlian yang khusus, sederhana (tanpa teknik aseptik) dan murah.

A. salina Leach memiliki beberapa kesamaan dengan mamalia, misalnya pada tipe DNAdependent RNA polimerase dari organisme ini serupa dengan yang terdapat pada mamalia yang juga memiliki ouabain sensitive $\mathrm{Na}^{+}$dan $\mathrm{K}^{+}$ dependent ATPase, sehingga senyawa maupun ekstrak yang menghambat aktivitas pada sistem tersebut secara langsung memiliki aktivitas antimitotik (Rizqillah. 2013).

\section{METODE PENELITIAN}

\section{Lokasi Pengambilan Sampel}

Pengambilan sampel

dilakukan dengan cara menyelam pada kedalaman sekitar 4-5 meter dibantu dengan alat selam atau SCUBA. Lokasi pengambilan sampel tersaji pada (Gambar 1) dengan memiliki titik koordinat $124 \div 47^{\circ} 31^{\circ} \mathrm{BT}$ dan $1^{\circ} 27^{\circ} 40^{\circ} \mathrm{LU}$. 


\section{Identifikasi Sampel}

Identifikasi dilakukan dengan cara mengamati morfologi sampel yaitu: bentuk dan warna sampel. Pengamatan morfologi karang lunak dipandu dengan buku "Tropical Pacific Invertebrates" (Colin dan Charles, 1995).

\section{Ekstraksi}

Sampel karang lunak dicuci terlebih dahulu menggunakan air tawar dan dipotong kecil diatas talenan kemudian dimasukkan ke dalam botol aqua, dimaserasi dengan menggunakan pelarut etil asetat, untuk sampel karang lunak dengan perbandingan 1:3 selama $1 \times 24$ jam pada suhu ruangan.

Sampel karang lunak masingmasing disaring dengan menggunakan kertas saring. Filtrat ditampung dalam wadah, selanjutnya dievaporasi menggunakan rotary vacuum evaporator pada suhu $400 \mathrm{C}$, sehingga diperoleh ekstrak pekat yang selanjutnya digunakan untuk pengujian sitotoksik.

\section{Pengujian Aktivitas Sitotoksik dengan Metode Brine Shrimp Lethality Assay (BSLA) \\ Uji toksisitas dengan larva} Artemia salina Leach mengikuti metode dalam Atta-ur-Rahman, dkk. (2005) yang dimodifikasi dengan langkah-langkah sebagai berikut : Media untuk larva dibuat dengan menyaring air laut sebanyak 5 liter, kemudian air laut yang sudah disaring diukur salinitasnya terlebih dahulu kemudian dimasukkan dalam akuarium yang sudah dibagi menjadi dua bagian, yaitu satu bagian dibuat gelap sebagai tempat penetasan dengan cara ditutup dengan kertas hitam dan bagian yang lain dibiarkan terbuka sebagai tempat pembesaran.

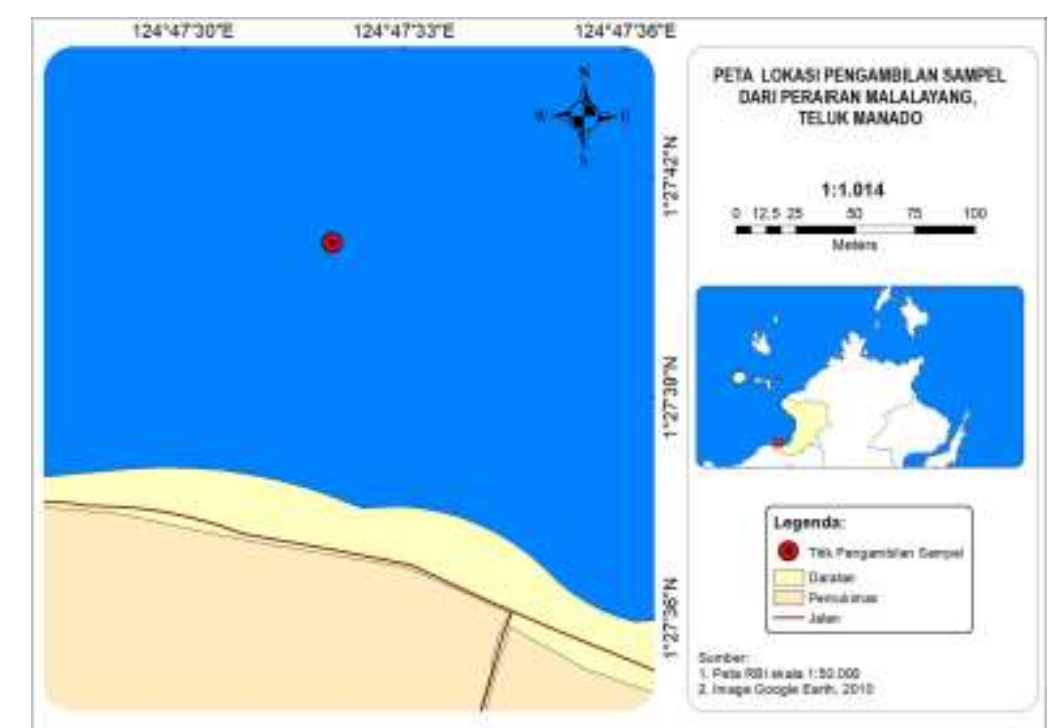

Gambar 1. Peta Lokasi Pengambilan Sampel dari Teluk Manado, Sulawesi Utara.

Selanjutnya telur $A$. salina diletakkan sebanyak 0,5 gram pada bagian yang gelap dan dibiarkan selama 48 jam sehingga telur menetas dan siap digunakan untuk pengujian. Ekstrak pekat spons dan karang lunak dihitung konsentrasi dalam ppm untuk menentukan berapa banyak ekstrak yang diambil dalam pengenceran bertingkat. Setelah mengetahui konsentrasi dari masing-masing ekstrak, kemudian dilakukan perhitungan untuk mengetahui volume awal yang digunakan dengan menggunakan rumus : 


$$
\begin{aligned}
& C 1 \times V 1=C 2 \times V 2 \\
& C 1=\text { Konsentrasi awal } \\
& C 2=\text { Konsentrasi akhir } \\
& V 1=\text { Volume awal } \\
& V 2=\text { Volume akhir }
\end{aligned}
$$

Setelah mengetahui volume awal yang digunakan dimasukkan ke dalam tabung reaksi dan langkah selanjutnya adalah air laut ditambahkan sampai volumenya 5 $\mathrm{ml}$ sehingga dicapai konsentrasi ekstrak yang 1000, 100, 50, 10, dan 1 ppm, sebanyak 10 larva dimasukkan ke dalam tabung reaksi. Masing-masing tabung reaksi ditutup dengan aluminium foil yang berlubang kecil-kecil, 24 jam kemudian dilakukan pengamatan terhadap kematian larva Artemia salina. Jumlah larva yang mati dicatat, kemudian dilakukan analisis data untuk menentukan konsentrasi kematian $\left(\mathrm{LC}_{50}\right)$.

\section{HASIL DAN PEMBAHASAN}

\section{Identifikasi Sampel}

Sampel yang diperoleh adalah karang lunak Xenia sp., (Gambar 2) yang didapatkan dengan ciri-ciri menyerupai jamur, dengan tangan keluar dari atas yang berakhir dengan tangan berjari banyak.

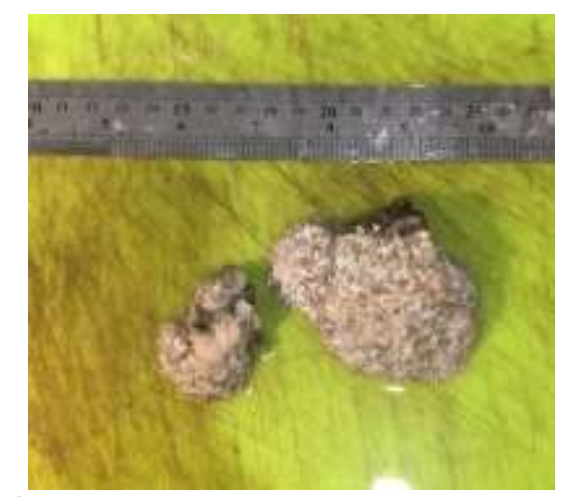

Gambar 2. sampel karang lunak Xenia sp., (Dokumentasi Pribadi, 2021

\section{Ekstraksi}

Sampel karang lunak Xenia sp., yang telah di ekstraksi dengan menggunakan metode maserasi menggunakan pelarut etil asetat, kemudian dievaporasi dan didapatkan ekstrak pekat karang lunak Xenia sp., sebanyak 16,6 g.

\section{Pengujian Sitotoksik}

Pengujian diawali dengan menetaskan telur larva udang selama $2 \times 24$ jam dengan menggunakan salinitas air laut sebesar 34 ppt. Hasil uji toksisitas menggunakan larva udang Artemia salina Leach pada ekstrak karang lunak Xenia sp., dengan menggunakan metode BSLA (Tabel 1) dengan memberikan data jumlah rata-rata kematian setiap ekstrak berdasarkan konsentrasi yang diberikan.

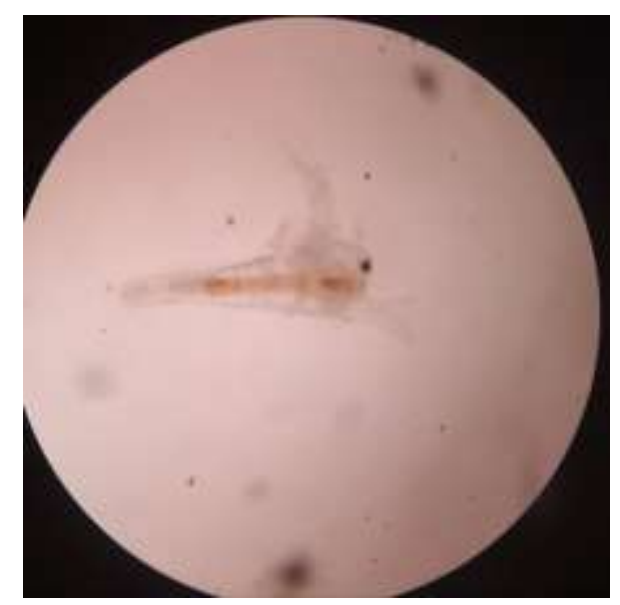

Gambar 3. Larva Artemia Salina yang sudah mati Perbesaran 100x (Dokumentasi Pribadi, 2021)

Dari data tabel yang disajikan, dilakukan perhitungan regresi linier dengan bantuan program Microsoft Excel untuk menentukan nilai LC S0. Pada (Gambar 4) yaitu hubungan antara log konsentrasi dengan nilai probit hasil uji toksisitas untuk ekstrak karang lunak Xenia sp. 
Dari grafik regresi linier didapatkan persamaan linier $y=a+$ bx dimana nilai a $(1,606)$ dan nilai $b$ $(2,5605)$ sehingga berdasarkan persamaan linier tersebut didapatkan nilai $\mathrm{LC}_{50}$ :

$y=a+b x$

$y=1,606+2,5605 x$

$5=1,606+2,5605 x$

$5-1,606=2,5605 x$

$3,394=2,5605 x$

$x=3,394 / 2,5605$

$x=1,32$

Antilog 1,32 $=20,89 \mathrm{ppm}$

$\mathrm{LC}_{50}=20,89 \mathrm{ppm}$

Model probit untuk karang lunak Xenia sp., adalah y $=1,606+$ 2,5605x. Dari persamaan tersebut diperoleh nilai $\mathrm{LC}_{50}$ dan sebesar 20,89 ppm. Dapat disimpulkan bahwa ekstrak Xenia sp., dikategorikan toksik berdasarkan klasifikasi Meyer atau toksik sedang berdasarkan klasifikasi Tanamatayarat, dan sangat toksik berdasarkan klasifikasi Clarkson.

BSLA merupakan tes untuk mengevaluasi toksisitas terhadap larva Artemia salina Leach. Ekstrak dengan kelas toksisitas tinggi berdasarkan hasil BSLT dapat digunakan untuk menunjukkan bahwa setidaknya satu senyawa dalam ekstrak memiliki aktivitas anti tumor dan sitotoksik (Ullah dkk., 2013).

Kelas toksisitas Meyer adalah ekstrak dengan $\mathrm{LC}_{50}<1000$ $\mathrm{mg} / \mathrm{L}$ dikaterogikan beracun, dan $\mathrm{LC}_{50}>1000 \mathrm{mg} / \mathrm{L}$ dikaterogikan tidak beracun (Meyer dkk., 1982). Sementara itu indeks Tanamatayarat mengklasifikasi tingkat toksisitas dengan kategori sangat toksik yaitu $\mathrm{LC}_{50}<10 \mathrm{mg} / \mathrm{L}$, toksik sedang yaitu $L_{50}: 10-100$ $\mathrm{mg} / \mathrm{L}$, toksik lemah yaitu $\mathrm{LC}_{50}: 100$ $1000 \mathrm{mg} / \mathrm{L}$, dan inaktif dengan LC $_{50}$ $>1000 \mathrm{mg} / \mathrm{L}$ (Tanamatayarat, 2016). Sedangkan klasifikasi toksisitas Clarkson adalah sebagai berikut: $\mathrm{LC}_{50}$ di atas $1000 \mathrm{mg} / \mathrm{L}$ dikategorikan tidak toksik, LC $_{50} 500$ - $1000 \mathrm{mg} / \mathrm{L}$ dikategorikan toksik rendah, $\mathrm{LC}_{50} 100$ - $500 \mathrm{mg} / \mathrm{L}$ dikategorikan toksik sedang, dan $\mathrm{LC}_{50} 0$ - $100 \mathrm{mg} / \mathrm{L}$ dikategorikan sangat toksik (Meena dkk., 2020).

Tabel 1. Hasil uji toksisitas ekstrak karang lunak Xenia sp., dengan menggunakan metode BSLA

\begin{tabular}{|c|c|c|c|c|}
\hline $\begin{array}{c}\text { konsentrasi } \\
(\mathrm{ppm})\end{array}$ & $\begin{array}{c}\text { log } \\
\text { konsentrasi } \\
(\mathrm{x})\end{array}$ & $\begin{array}{c}\text { rerata } \\
\text { kematian }\end{array}$ & $\begin{array}{c}\% \\
\text { mati }\end{array}$ & $\begin{array}{c}\text { Probit } \\
(\mathrm{y})\end{array}$ \\
\hline 0 & $\begin{array}{c}\text { Kontrol } \\
\text { negatif }\end{array}$ & 0,0 & $0 \%$ & 0 \\
\hline 1 & 0 & 0,0 & $0 \%$ & 1,03 \\
\hline 10 & 1 & 4,0 & $40 \%$ & 4,75 \\
\hline 50 & 1.6 & 9,0 & $90 \%$ & 6,28 \\
\hline 100 & 2 & 9,3 & $93 \%$ & 6,48 \\
\hline 1000 & 3 & 10,0 & $100 \%$ & 8,95 \\
\hline
\end{tabular}




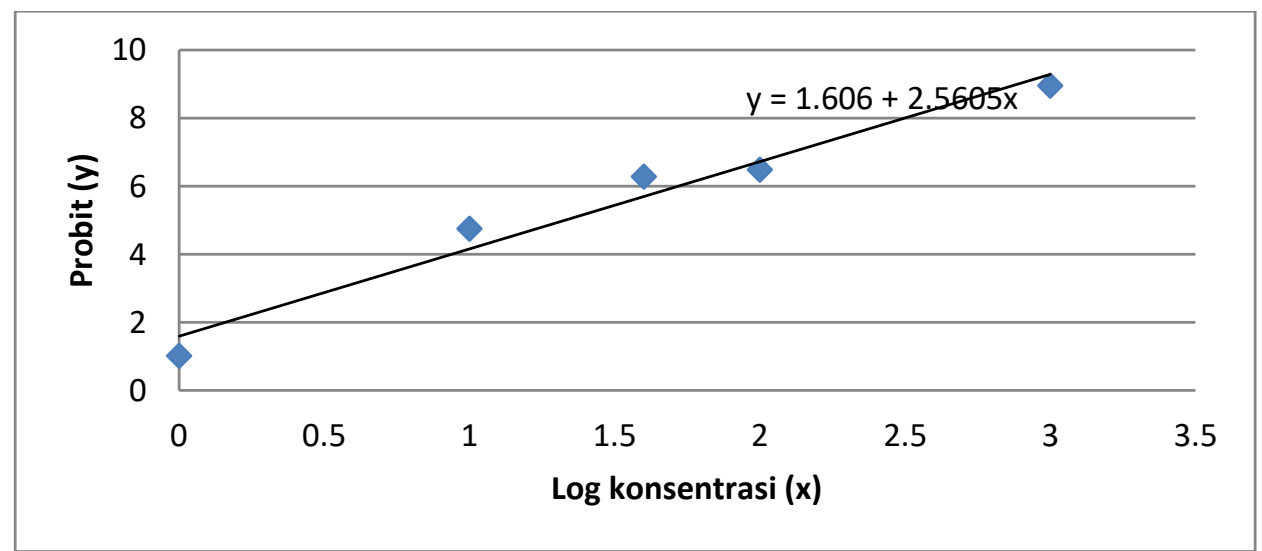

Gambar 4. Hubungan antara log konsentrasi dengan nilai probit hasil uji toksisitas ekstrak karang lunak Xenia sp.

Analisa data berdasarkan perhitungan mortalitas larva yang mati pada pengamatan 24 jam dan perhitungan nilai lethal concentration $50 \%\left(\mathrm{LC}_{50}\right)$ dilakukan analisis probit. Analisis probit umumnya digunakan dalam toksikologi untuk menentukan toksisitas relatif dari bahan kimia untuk organisme hidup. Hal ini dilakukan dengan menguji respon organisme di bawah berbagai konsentrasi masing-masing bahan kimia tersebut dan kemudian membandingkan konsentrasi (Jelita dkk., 2020).

Penelitian dari biota karang lunak telah dilakukan oleh Dhone dkk (2018) yang melaporkan penelitian tentang uji toksisitas ekstrak karang lunak Sarcophyton sp., dari perairan laut pantai Paradiso, Kupang, sampel karang lunak ini dimaserasi menggunakan pelarut n-heksana, etil asetat dan metanol lalu dievaporasi pada suhu $40^{\circ} \mathrm{C}$ dan $45^{\circ} \mathrm{C}$ hingga didapatkan ekstrak kental. Ekstrak kental kemudian diuji kandungan metabolit sekunder serta uji toksisitas menggunakan metode BSLA. Hasil uji metabolit sekunder menunjukkan ekstrak metanol positif mengandung saponin, fenol dan steroid sedangkan ekstrak etil asetat positif mengandung steroid dan terpenoid. Hasil uji toksisitas menunjukkan ekstrak metanol dan etil asetat Sarcophyton sp., bersifat sangat toksik dengan nilai $\mathrm{LC}_{50}$ masing-masing 29,56 dan 34,11 ppm.

$\begin{array}{cr}\text { Seperti } & \text { yang sudah } \\ \text { dijelaskan } & \text { sebelumnya }\end{array}$ pendahuluan untuk senyawa yang bersifat antikanker umumnya menggunakan uji toksisitas terhadap larva Artemia salina Leach. Jika dalam uji tersebut suatu bahan mempunyai $\mathrm{LC}_{50}$ lebih kecil dari 1000 ppm maka bahan tersebut berpotensi sebagai antikanker. Dari penelitian yang sudah dilaporkan dapat dilihat bahwa karang lunak Xenia sp., memiliki tingkat toksisitas yang lebih tinggi dari biota karang lunak yang lain.

\section{KESIMPULAN DAN SARAN}

\section{Kesimpulan}

Hasil pengujian aktivitas sitotoksik pada sampel ekstrak karang lunak Xenia sp., memiliki sifat toksik yang kuat, sehingga dapat diteliti lebih lanjut kandungan senyawa yang berpotensi sebagai antikanker.

\section{Saran}

Pengujian sitotoksik dapat dilanjutkan dengan partisi untuk mengetahui di fraksi mana sampel tersebut berada. 


\section{DAFTAR PUSTAKA}

Atta-ur-Rahman,. M.I. Choudhary dan W.J. Thomson. 2005. ToxicityAssays; BrineShrimp Lethality Assay. Amsterdam, the Netherlands, harwood academic publishers.

Colin, P.L. dan Charles. A. 1995. Tropical Pacific Invertebrates: A Field Guide to the Marine Invertebrates Occuring on Tropical Pacific Coral Reefs, Seagrass Beds and Mangroves. Coral Reef Press. Beverly Hills, California. USA.

Cordeiro R., van O. L., dan Williams G. 2019. World List of Octocorallia. Xeniidae Ehrenberg, 1828. World Register of Marine Species.

http://www.marinespecies. org/aphia.

php? $p=$ taxdetails \&id $=1252$ 71 [Accessed on 2019-0228].

Dhone B.S., T. D. Cunha. dan D. Darmakusuma. 2018. Uji Toksisitas Ekstrak Karang Lunak Sarcophyton sp. Asal Timor Terhadap Larva Artemia Salina Leach. Skripsi.1(1), 32-40.

Jelita, S.F., G. W. Setyowati., M. Ferdinand., A. Zuhrotum, dan S. Magantara. 2020. Uji Toksisitas Infus Acalypha Siamensis dengan Metode Brine Shrimp Lethality (BLST). Farmaks vol 18 No.1.

Kanwar, A.S. 2007. Brine Shrimp (Artemia salina) a Marine Animal for Simple and Rapid Biological Assays. Chinese Clinical Medicine 2 (4): 35-42.

Leal, M.C., J. Puga., J. Serodio., N. C. M. Gomes., dan R.
Calado. 2012. Trends in the Discovery of New Marine Natural Products from Invertebrates Over the Last Two DecadesWhere and What Are We Bioprospecting? Plos ONE 7

[1]:e30580.Doi:10.1371/jou rnal.pone.0 030580.

Meena, D. K., A.K Sahoo., H. S. Swain., S. Borah., P. P. Srivastava., N. P. Sahu., dan B. K. Das (2020). Prospects and perspectives of virtual invitro toxicity studies on herbal extracts of Terminalia arjuna with enhanced stratagem in Artemia salina model: A panacea to explicit the credence of solvent system in brine shrimp lethality bioassay. Emirates Journal of Food and Agriculture, 32(1), 25-37.

Meyer, B. N., N. R. Ferrigni., J. E. Putnan., L. B. Jacobsen., D. E. Nicolas., dan J. L. McLaughlin. 1982. Brine Shrimp: A Convenient General Bioassay for Active Plant Constituent. Departement of Medical Chemistry and Pharmakognosy, School of Pharmacy and Pharmacal Science and Cell Culture Libratory, Purdue Cancer Center.West Lavayette. USA.

Nursid, M., T. Wikanta., N. W. Fajarningsih., dan E. Marraskuranto. 2006. Aktivitas Sitotoksik, Induksi Apoptosis dan Ekspresi Gen p53 Fraksi Metanol Spons Petrosia cf. nigricans terhadap Sel Tumor Hela, Jurnal Pascapanen dan 
Bioteknologi Kelautan dan Perikanan, 1(2).

Radhika, P. 2006. Chemical Constituents and Biological Activities Of The Soft Coral Of Genus Cladlella: A Review, Biochemical Systematic and Ecological, 34: 781-789.

Radjasa, O. K., D. S. Kencana., A. Sabdono., R. A. Hutagalung dan E. S. Lestari. 2007. Antibacterial Activity of Marine Bacteria Associated with sponge Aaptos sp. against Multi Drugs Resistant (MDR) strains. Jurnal Matematika Dan Sains, 12 (4); 147152.

Tanamatayarat, P. (2016). Antityrosinase,

antioxidative activities, and brine shrimp lethality of ethanolic extracts from Protium serratum (Wall. ex Colebr.) Engl. Asian Pacific Journal of Tropical Biomedicine, 6(12), 10501055. 